\title{
The Importance of Mineral Industry (Smelter) for the Future Industrial Development in East Java
}

\author{
Sungging Pintowantoro, ${ }^{1, *}$, Fakhreza Abdul ${ }^{1}$, Yuli Setiyorini ${ }^{1}$ \\ ${ }^{1}$ Department of Materials and Metallurgical Engineering, Faculty of Industrial Technology and System \\ Engineering, Institut Teknologi Sepuluh Nopember, Arief Rahman Hakim Street, Surabaya 60111, Indonesia \\ "Corresponding author. Email: sungging@mat-eng.its.ac.id
}

\begin{abstract}
East Java is the second largest province which contributes to the national Gross Regional Domestic Product, which is around $14.57 \%$ in 2020 . The processing industry sector contributes almost $31 \%$. So, it can be concluded that the processing industry is the main economic pillar of East Java. The mineral processing (smelter) industry is one of the processing industries that have high revenue potential. A smelter industry requires several main raw materials, namely ore, fuel, and additives. East Java has abundant mineral potential, especially dolomite, limestone, and iron sand. East Java is a province that is relatively ready for the development of the smelter industries. East Java has the largest installed power plant in Indonesia. With so many coal-based power plants, more fly ash is produced. Fly ash is currently known to have the potential for Rare Earth Elements (REE). The REE can be used for renewable energy materials. Thus, with the increasing demand for energy and environmentally friendly transportation, East Java has the potential to become the center of the REE extraction industry from fly ash sources. In addition, East Java also has adequate infrastructure, has many cement industries that can utilize slag, and close to the market. There are multiplier effects for business processes in the development and operation of the smelting industry, starting from the investment stage, smelting operations, and sales. In the future, East Java has potential to become a smelter industry center for Eastern Indonesia as well as a center for REE extraction from coal fly ash.
\end{abstract}

Keywords: East Java, Sustainable, Sustainable mineral industry, Smelter, Rare Earth Element.

\section{INTRODUCTION}

East Java is the second largest province that contributes to the national Gross Regional Domestic Product (GRDP), which is around $15 \%$ in 2020 (processed from C.B.o.S.o.R.o.I, 2021 ${ }^{1}$ ). The processing industry sector contributed about $20 \%$ in the first quarter of 2021 of the total national gross domestic product by business field (processed from C.B.o.S.o.R.o.I, 20212). Meanwhile, if viewed from a regional scale in the first quarter of 2021, East Java's Gross Regional Domestic Product for the manufacturing sector contributed almost $31 \%$ of the total gross regional domestic product of all types of business fields (processed from C.B.o.S.o.R.o.I, $2021^{3}$ ). Thus, in the business sector in the manufacturing sector, East Java's gross regional domestic product is higher than the national one. Based on this, it can be concluded that the processing industry is the main economic pillar of East Java. The mineral processing and smelter industry are some of the processing industries that have high revenue potential. In the course of its business, a smelter has several stages of business schemes, starting from investment, production, and sales. At the investment stage, business processes will occur between mining landowners, mining contractors, investors, technology providers, independent consultants, and regional or private companies. At this stage, there is a business consortium for the establishment of a smelter plant. Furthermore, when the smelter is operating, there are several stakeholders involved, starting from the internal party of the smelter plant, vendors providing raw materials for the smelter plant, both raw materials for ore-bearing metal, fuel, additives (eg lime, dolomite, $\mathrm{CaF}_{2}$ ), and other materials. In addition, when operating, the smelter plant will also produce by-products other than the main product. This product can also be used by other parties to generate income. Furthermore, the excess energy generated by the operating smelter can also be used to generate income. Even so, the waste produced also costs money to process in an environmentally friendly way. This can actually also be used by parties other than the internal smelter itself to earn income. Then, the main product produced by the smelter can be sold to earn income. So that the development of a smelter industry has a large multiplier effect for the regional and national economy of East Java. Figure 1 shows the impact of the relationship between business processes in the development and operation of the smelting industry, starting from the investment stage, smelting operations, and sales (Redrawn based on Hanafi, et al, 2014 in Hanafi, et al, 2019). This paper aims to provide an overview of the importance of developing 
the smelting industry in East Java, Indonesia by reviewing several potential areas of East Java, ranging from mineral potential and rare earth metal potential in coal fly ash.

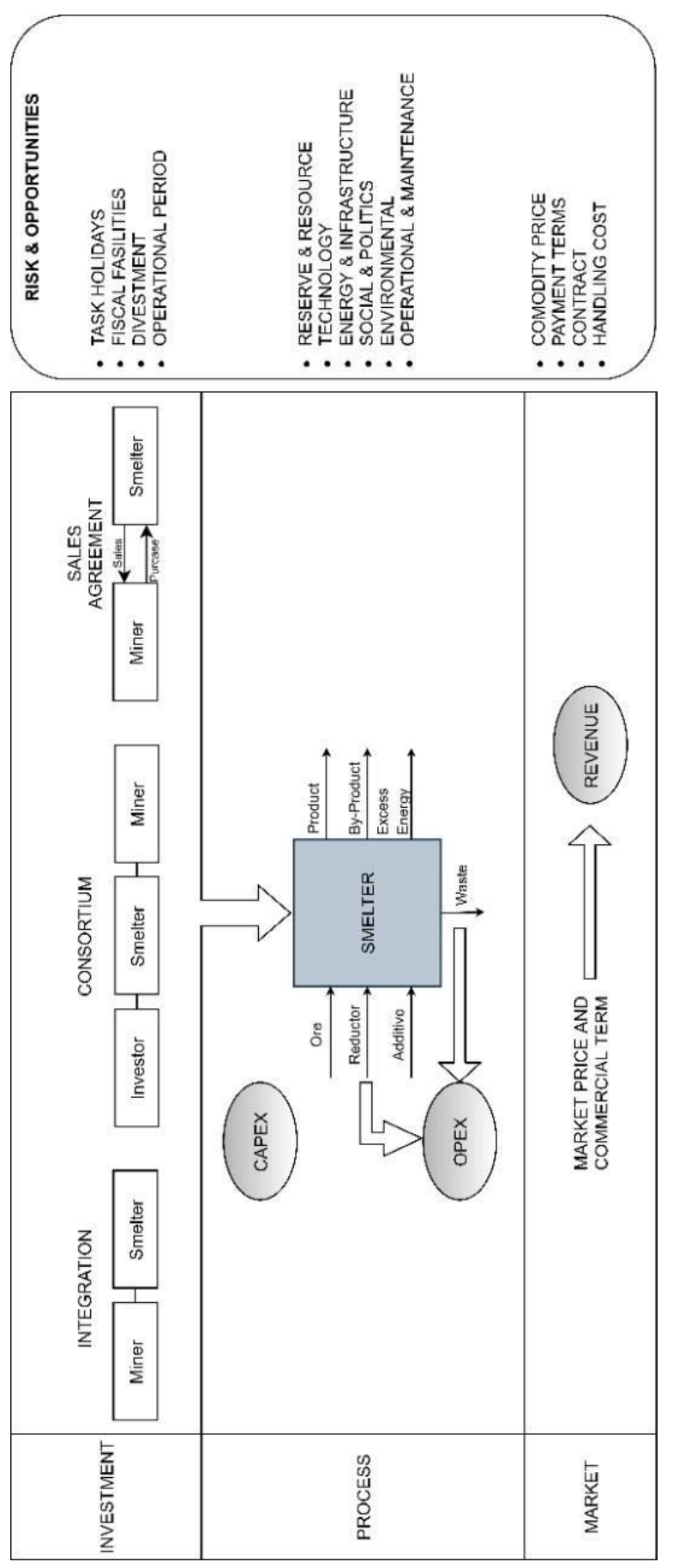

Figure 1. The impact of the relationship between business processes in the construction and operation of the smelter industry (Redrawn based on Hanafi, et al, 2014 in Hanafi, et al, 2019).

\section{POTENTIAL OF MINERALS IN THE EAST JAVA REGION}

The most dominant minerals in East Java are dolomite and limestone. Dolomite and limestone minerals are very much needed by the smelter industry as flux materials. In smelter operations, fluxes are important compounds to help improve smelter operations. Flux serves to bind impurities in the raw material (Pintowantoro, S., 2021 ${ }^{1}$ ). Various types of fluxes can be used in smelter operations, such as dolomite, limestone, burnt lime, dolomite lime, feldspar, and others. Of all these types of fluxes, dolomite and limestone fluxes are the most common fluxes in East Java. Dolomite is a natural white mineral with a chemical formula of $\mathrm{CaMg}\left(\mathrm{CO}_{3}\right)_{2}$. On the other hand, limestone is a natural white mineral with a chemical formula of $\mathrm{CaCO}_{3}$. Table 1 shows the typical chemical composition of dolomite and limestone for metallurgical applications.

Table 1. Typical chemical composition of dolomite and limestone (Pintowantoro, S., 2021 ${ }^{1}$ )

\begin{tabular}{|l|c|c|c|c|c|c|}
\hline Item & $\mathrm{CaCO}_{3}$ & $\mathrm{MgCO}_{3}$ & $\mathrm{SiO}_{2}$ & $\mathrm{Fe}_{2} \mathrm{O}_{3}$ & $\mathrm{Al}_{2} \mathrm{O}_{3}$ & Other \\
\hline Dolomite & 52.40 & 40.00 & 6.80 & 0.30 & 0.30 & Bal. \\
\hline Limestone & 93.80 & 3.60 & 1.80 & 0.30 & 0.20 & Bal. \\
\hline
\end{tabular}

In East Java, dolomite and limestone minerals are mostly located along the Madura and Rembang Hills. Dolomites are located in Pacitan, Tuban, Lamongan, Gresik, Sampang, and Pamekasan areas. While limestone is in the Pacitan, Blitar, Nganjuk, Tuban, Bondowoso, and Sampang areas (D.o.E.a.M.R.o.E.J.P., 2016). East Java's dolomite mineral potential is around 219 million tons. Pamekasan contributes about $92 \%$ of the total dolomite potential in East Java. On the other hand, the potential for limestone in East Java is around 17 million tons. Blitar contributes about $89 \%$ of the total limestone potential in all of East Java (D.o.E.a.M.R.o.E.J.P., 2016).

In addition to dolomite and limestone, metallic minerals in East Java are iron sand. Iron sand is an alternative raw material in the manufacture of iron and steel. Iron sand has the main mineral in the form of Titanomagnetite $\left(\mathrm{Fe}_{3-\mathrm{x}} \mathrm{Ti}_{\mathrm{x}} \mathrm{O}_{4}\right)$ (Wang, $\left.\mathrm{Z}, 2016\right)$. Indonesia has iron sand deposits of around 2,121 million tons (M.o.E.a.M.R.o.R.o.I., 2014 in Pintowantoro, S, 2021², Abdul, 2019). In East Java, the potential for iron sand is around 736 million tons. Trenggalek contributes about $95 \%$ of the total iron sand potential in East Java (D.o.E.a.M.R.o.E.J.P., 2016). The typical chemical composition of iron sand (after beneficiation using magnetic separation) from Lumajang, East Java is $51.238 \% \mathrm{Fe}, 23.731 \% \mathrm{Si}, 3.923 \% \mathrm{Mg}, 1.619 \% \mathrm{Ti}$, $0.713 \%$ Ca. For comparison, the typical chemical composition of iron sand from Sukabumi, West Java, Indonesia is $57.93 \% \mathrm{Fe}, 8.46 \% \mathrm{Ti}, 3.40 \% \mathrm{Si}, 2.72 \% \mathrm{Mg}$, 
2.66\% $\mathrm{Al}$ (Abdul, F, 2018). Iron sand is an alternative raw material in the process of sponge iron making. The sponge iron will then be further processed to produce pig iron and steel. After being processed into sponge iron or steel, iron sand has a high added value increase. Table 2 shows the typical composition of sponge iron processed from iron sand raw material from the Lumajang area, East Java, Indonesia.

Table 2. Chemical composition of iron sand concentrate and sponge iron processed from iron sand obtained from Lumajang, East Java, Indonesia

\begin{tabular}{|c|c|c|c|c|c|c|}
\hline & $\mathrm{Fe}$ & $\mathrm{Si}$ & $\mathrm{Mg}$ & $\mathrm{TiO}_{2}$ & $\mathrm{Ca}$ & Trace \\
\hline $\begin{array}{c}\text { Iron sand } \\
\text { concentrate }\end{array}$ & 51.24 & 23.73 & 3.92 & $\begin{array}{c}1.62 \\
\text { (as } \\
\mathrm{Ti}\end{array}$ & 0.71 & Bal. \\
\hline $\begin{array}{c}\text { Sponge } \\
\text { Iron }\end{array}$ & 64.80 & 5.10 & 5.00 & 3.70 & 0.40 & Bal. \\
\hline
\end{tabular}

Indonesia's iron sand and iron ore sector have the highest output multiplier value compared to other mining commodities. With an increase of one unit of demand for an iron sand and iron ore commodities, it will increase the economy by $184 \%$ (Tui, RNS, 2021).

\section{POTENTIAL OF RARE EARTH METALS IN COAL FLY ASH}

Rare Earth Element (REE) is currently a commodity that is experiencing a high increase in demand. The high market demand for REE is due to the increasing human need for advanced technology, such as computer memory, super magnets, batteries, solar cell panels, LEDs, and many more. (Balaram, V, 2019). REE consists of 15 elements Lanthanides, yttrium, and scandium (Balaram, V, 2019, Castor, SB, 2006 in Rybak, A, 2021). REE can be classified into three groups, namely (i) critical, (ii) uncritical, and (iii) excessive. The critical REE group consists of Dy, Er, Eu, Nd, Tb, Y. The uncritical REE group consists of Gd, La, Pr, and Sm. Meanwhile, the REE excessive group consisted of Ce, Ho, Lu, Tm, and Yb. (Seredin, 2012 in Franus, 2015). REE demand is increasing day by day. In 2010, global REE demand was around 105,000 tonnes per year. Thus, by 2030, it is estimated that REE demand will be over 200,000 tonnes per year (Alonso, 2012). Coal fly ash has recently been found to contain significant amounts of REE (Franus, 2015). The chemical composition of the elements in coal fly ash is highly dependent on the natural characteristics of the coal and the coal combustion process itself. Coal fly ash has various types of REE, such as $\mathrm{La}, \mathrm{Ce}, \mathrm{Pr}, \mathrm{Nd}, \mathrm{Sm}, \mathrm{Eu}, \mathrm{Gd}, \mathrm{Tb}, \mathrm{Y}$, and others. However, among the REEs contained in coal fly ash, the REE types of $\mathrm{La}, \mathrm{Ce}, \mathrm{Nd}$, and $\mathrm{Y}$ are REEs that have relatively higher content than other REE types. (Franus, 2015). The REE concentration in fly ash is higher than the REE concentration in natural coal. This is because coal still contains quite a lot of volatile matter. On the other hand, fly ash does not contain volatile matter because it has undergone a combustion process (CalusMozko and Bialecka, 2013 in Franus, 2015).

East Java has an installed power plant capacity of $11,072.58 \mathrm{MW}$, or in other words, ranks first in the province with the largest installed capacity of electricity generation in Indonesia (C.B.o.S.o.R.o.I, 20214). With this figure, East Java contributes around $16.6 \%$ of the total installed capacity of Indonesia's power plants. Because the majority of power plants in East Java are PLTU types, the PLTU's fly ash produced is also very large. The potential of REE in coal fly ash produced at PLTU in East Java must be utilized properly. Moreover, so far coal fly ash has only been disposed of and has been used very little further. The use of fly ash has so far been limited to applications for making concrete and geopolymers (Darmawan, MS, 2015, Bayuaji, R, 2016, Darmawan, MS, 2019). Currently, coal fly ash in Indonesia is no longer classified as dangerous and toxic materials waste, based on Government Regulation no. 22 of 2021 concerning the implementation, protection, and management of the environment (C.S.o.R.o.I, 2021). Therefore, the use of coal fly ash is easier from a regulatory perspective. As a first step, East Java Province should start mapping the REE potential in coal fly ash in the East Java region. After that, it is necessary to do research and calculate whether the fly ash content in coal in East Java Province is feasible to be processed and generate sustainable revenue. If after a comprehensive study it is concluded that the REE extraction process from coal fly ash can generate revenue and is economical, then East Java may be able to become the first REE processing center from fly ash raw materials in Indonesia.

\section{OTHER ASPECTS THAT SUPPORT EAST JAVA AS THE CENTER OF THE SMELTER INDUSTRY FOR THE EASTERN INDONESIA REGION}

In addition to the potential of non-metallic minerals (dolomite and limestone), metallic minerals (iron sand), and REE in coal fly ash, East Java is also a province that is considered most ready to become the center of the processing industry through the establishment of a smelter. There are at least 11 ports in East Java with a loading and unloading capacity of around 28 billion tons per year in 2018 (C.B.o.S.o.R.o.I, 20215 ). East Java has 60,892 business units in the fields of metal, machinery, and transportation equipment, some of which can become a market for smelter industry products. East Java has many cement industries that can accommodate and utilize slag from the smelter industry. East Java has many industrial areas. Currently, there are at least 10 industrial areas in East Java (East Java net, 2021). East Java has adequate land transportation access with almost all 
regencies/cities in East Java connected by toll roads. East Java is geographically located in a strategic position that can connect various provincial capital cities in Eastern Indonesia. As we know, eastern Indonesia has abundant potential for metallic and non-metallic minerals. Figure 2 shows an illustration of the potential of East Java as the center of the Smelter Industry for the Eastern Indonesia region.

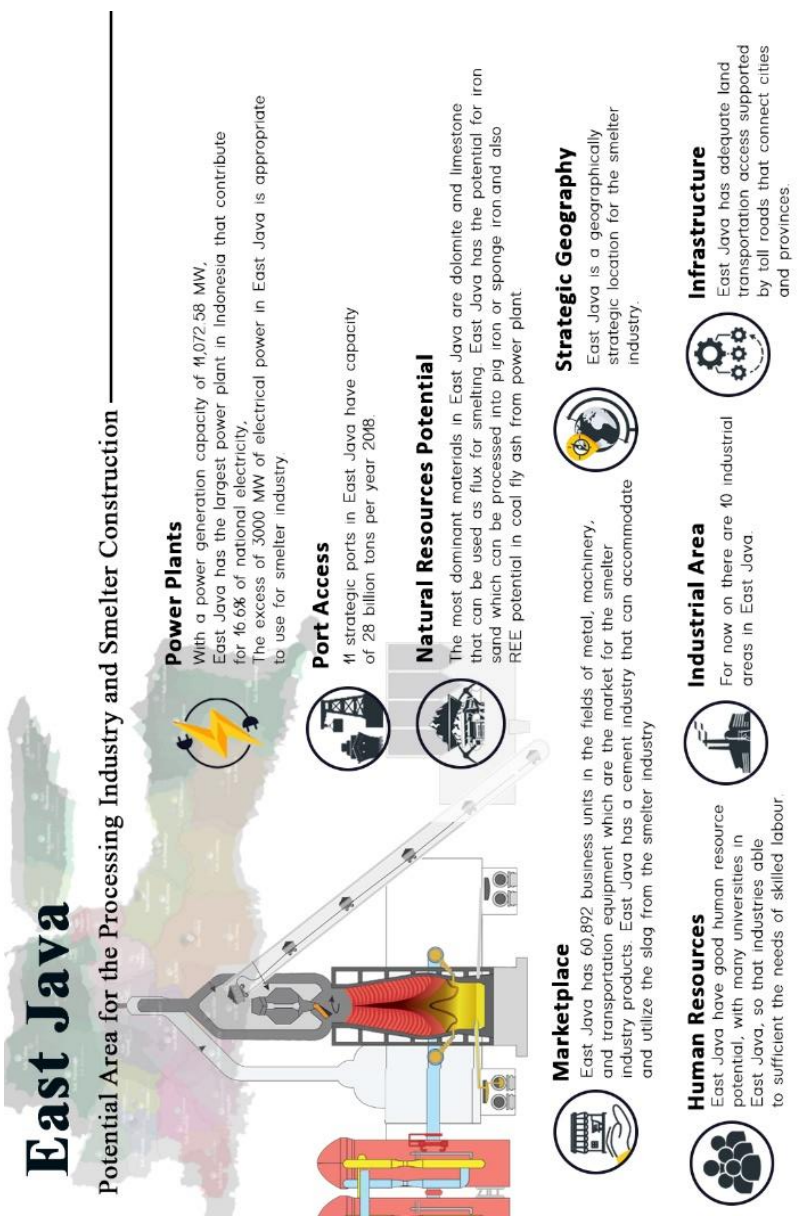

Figure 2. Illustration of the potential of East Java as the center of the Smelter Industry for the Eastern Indonesia region.

\section{CONCLUSION}

East Java has the potential to become the center of the processing industry or smelter. East Java is a province that is relatively ready for the construction and development of the smelter industry. East Java has the largest installed power plant in Indonesia. With so many power plants in East Java, more and more fly ash is produced. Fly ash itself is currently known to have the potential for rare earth elements (REE). This REE can be used for renewable energy materials. Thus, with the increasing demand for energy and environmentally friendly transportation, East Java has the potential to become the center of the Rare Earth Metal extraction industry from fly ash sources. In addition, East Java also has adequate transportation support infrastructure, has many cement industries that can utilize solid waste (slag) produced by smelters, and is close to the market. Geographically, East Java can become the center of the smelter industry for eastern Indonesia which is rich in minerals. So, in the future, East Java has the potential to become a metal industry center for Eastern Indonesia as well as an industrial center for extracting rare earth metals from coal fly ash as raw material.

\section{AUTHORS' CONTRIBUTIONS}

Sungging Pintowantoro contributed to data collection, article writing, data analysis, making figures and tables, and formulating conclusions. Sungging Pintowantoro roles as corresponding author for this article. Fakhreza Abdul and Yuli Setiyorini contributed to data collection, article writing, data analysis, making figures and tables.

\section{ACKNOWLEDGMENTS}

The author would like to thank the Institut Teknologi Sepuluh Nopember, Surabaya, Indonesia for the funding that has been provided through the "Penelitian Kolaborasi Pusat" scheme with Contract Number: 1237/PKS/ITS/2021.

\section{REFERENCES}

[1] C.B.o.S.o.R.o.I (Central Bureau of Statistics of the Republic of Indonesia), $2021^{1}$, accessed at July, 3 , 2021, website address: https://www.bps.go.id/indicator/52/286/1/-seri2010-produk-domestik-regional-bruto-.html

[2] C.B.o.S.o.R.o.I (Central Bureau of Statistics of the Republic of Indonesia), 2021 ${ }^{2}$, accessed at July, 3, 2021, website address https://www.bps.go.id/indicator/11/65/1/-seri2010-pdb-seri-2010.html

[3] C.B.o.S.o.R.o.I (Central Bureau of Statistics of the Republic of Indonesia), 2021 ${ }^{3}$, accessed at July, 3, 2021, website address https://Jawa Timur.bps.go.id/indicator/52/479/1/-seri-2010pdrb-menurut-lapangan-usaha-17-sektortriwulanan-.html

[4] Hanafi, M, Wibisono, D, Mangkusubroto, K, Siallagan, M, Jamilah, M, Badriyah, K, Designing smelter industry investment competitiveness policy in Indonesia through system dynamic model, Journal of Science and Technology Policy Management, 10, 3, 2019, pp. 617-641, https://doi.org/10.1108/JSTPM-06-2018-0064

[5] Hanafi, M., Soemantri, S. and Hikmat, M., Roadmap Reformulation: Copper Smelter Industry Development by Using Domestic Resources in 
Indonesia, Directorate of Basic Metal Material Industry Ministry of Industry, Jakarta, 2014.

[6] Pintowantoro, S, Abdul, F, Introduction to Ironmaking Process: Main Process and its Alternative, Airlangga University Press, Surabaya, $2021^{1}$, In Bahasa Indonesia

[7] D.o.E.a.M.R.o.E.J.P. (Department of Energy and Mineral Resources of East Java Province, 2016, Energy and Mineral Resources in number 2016, http://esdm.Jawa

Timurprov.go.id/esdm/attachments/article/89/esdm \%20dalam\%20angka\%202016.pdf

[8] Z. Wang, D. Pinson, S. Chew, H. Rogers, B.J. Monaghan, G. Zhang, Interaction of New Zealand Ironsand and Flux Materials, ISIJ International, 56, 2016 , pp.1315-1324. https://doi.org/10.2355/isijinternational.ISIJINT$\underline{2015-728}$

[9] M.o.E.a.M.R.o.R.o.I. (Ministry of Energy and Mineral Resources of the Republic of Indonesia), Steel Industry Profile in Bahasa Indonesia, 2014.

[10] Pintowantoro, S, Abdul, F, Sanubari, F, Study of the effect of binder types on the reduction process and metallurgical properties of Indonesian titanomagnetite iron sand in the point of view of tunnel kiln process, Journal of Chemical Technology and Metallurgy, 56, 1, 2021², pp. 227234, $\quad$ https://dl.uctm.edu/journal/node/j20211/25_19-141_p_227-234.pdf

[11] Abdul, F, Pintowantoro, S, Hidayatullah, AB, Analysis of Cylindrical Briquette Dimension on Total Iron Content and the Degree of Metallization in Direct Reduction Process of Iron Ore and Iron Sand Mixture, Materials Science Forum, 964, 2019, pp.

$19-25$, https://doi.org/10.4028/www.scientific.net/msf.964 .19

[12] Abdul, F, Wasik, H, Analysis of the Use of Several Types of Local Charcoal as Reductants in the Process of Making Sponge Iron from Iron Sand Raw Materials Using the Direct Reduction Method, J. IPTEK, 22, 2, 2018, pp. 43-50, In Bahasa Indonesia, https://doi.org/10.31284/j.iptek.2018.v22i2.417

[13] Tui, RNS, Adachi, T, An input - output approach in analyzing Indonesia's mineral export policy. Miner Econ 34, , 2021, pp. 105-112. https://doi.org/10.1007/s13563-020-00226-3

[14] Balaram, V, Rare earth elements: A review of applications, occurrence, exploration,analysis, recycling, and environmental impact, Geosciences
Frontiers, 10, 2019, pp. 1285-1303. https://doi.org/10.1016/j.gsf.2018.12.005

[15] Castor, S.B.; Hendrik, J.B. Industrial Minerals and Rocks: Commodities, Markets and Uses; Society of Mining Mineralogy: Englewood, CO, USA, 2006; Volume 7, pp. 769-792.

[16] Rybak, A, Rybak, A, Characteristics of Some Selected Methods of Rare Earth Elements Recovery from Coal Fly Ashes, Metals, 11, 142, 2021, pp. 128, https://doi.org/10.3390/met11010142

[17] Seredin, VV, Dai, S, Coal deposits as potential alternative sources for lanthanides and yttrium. Int J Coal Geol, 94, 2012, pp. 67-93, https://doi.org/10.1016/j.coal.2011.11.001

[18] Franus, W, Wlatros-Motyka, MM, Wdowin, M, Coal fly ash as a resource for rare earth elements, Environ. Sci. Pollut. Res., 22, 2015, pp. 9464-9474. DOI: $10.1007 / \mathrm{s} 11356-015-4111-9$

[19] Alonso, E, Sherman, AM, Wallington, TJ, Everson, MP, Field, FR, Roth, R, Kirchain, RE, Evaluating Rare Earth Element Availability: A Case with Revolutionary Demand from Clean Technologies, Environ. Sci. Technol., 46, 2012, pp. 3406-3414. DOI: dx.doi.org/10.1021/es203518d

[20] Całus-Moszko, J, Białecka, B, Analiza możliwości pozyskania pierwiastków ziem rzadkich z węgli kamiennych i popiołów lotnych z elektrowni. Gosp Sur. Miner. Miner. Res. Manag., 29, 1, 2013, pp. 6780

[21] C.B.o.S.o.R.o.I (Central Bureau of Statistics of the Republic of Indonesia), $2021^{4}$, accessed at July, 3, 2021, website address: https://www.bps.go.id/indicator/7/869/1/kapasitasterpasang-pembangkit-listrik-menurutprovinsi.html

[22] Darmawan, MS, Bayuaji, R, Husin, NA, Chomaedi, Saud, I, A Case Study of Low Compressive Strength of Concrete Containing Fly Ash in East Java Indonesia, Procedia Engineering, 125, 2015, pp.

$579-586$

https://doi.org/10.1016/j.proeng.2015.11.064

[23] Subekti, S, Bayuaji, R, Darmawan, MS, Husin, NA, Wibowo, B, Anugraha, B, Irawan, S, Dibiantara, D, Review: Potential strength of fly ash-based geopolymer paste with substitution of local waste materials with high temperature effect, IOP Conf. Ser. Mater. Sci. Eng., 267(1):012001, 2017, DOI:10.1088/1757-899X/267/1/012001

[24] Darmawan, MS, Bayuaji, R, Sugihardjo, H, Husin, NA, Affandhie, RBA, Shear Strength of Geopolymer Concrete Beams Using High Calcium 
Content Fly Ash in a Marine Environment, Buildings 9, 4, 2019, 98, https://doi.org/10.3390/buildings9040098

[25] C.S.o.R.o.I (Cabinet Secretariat of Republic of Indonesia),

2021, https://jdih.setkab.go.id/PUUdoc/176367/PP Nom or_22_Tahun_2021.pdf

[26] C.B.o.S.o.R.o.I (Central Bureau of Statistics of the Republic of Indonesia), 2021 ${ }^{5}$, accessed at July, 3, 2021, website address: , https://Jawa Timur.bps.go.id/statictable/2019/10/09/1702/volu me-dan-nilai-impor-provinsi-jawa-timur-menurutpelabuhan-bongkar-2017-dan-2018.html

[27] East Javanet, 2021, accessed at July, 3, 2021, website address: https://Jawa Timurnet.com/10kawasan-industri-di-jawa-timur 